\title{
The Adoption of Information Technology in the Governance System of the Bank of Namibia
}

Tjikarerera C. T. Kahorongo ${ }^{1}$, Nishika Reddy ${ }^{1}$, Anis Mahomed Karodia ${ }^{1}$

${ }^{1}$ Regent Business School, Republic of South Africa

Correspondence: Anis Mahomed Karodia, Professor, Senior Academic and Researcher, Regent Business School, Durban, Republic of South Africa

\author{
Received: December 23, 2014 Accepted: January 7, 2015 Online Published: June 11, 2015 \\ doi:10.11114/bms.v1i2.876 \\ URL: http://dx.doi.org/10.11114/bms.v1i2.876
}

\begin{abstract}
The failure of many organisations over the years has led to a greater need for transparency and accountability. The Corporate Governance Framework, as developed by the King report, is the overarching framework that ensures that the board of directors are responsible for the governance of an organisation. The King III report implies that the board should also be responsible for IT governance because IT is a crucial and costly component that enables the achievement of organisational objectives. From several IT Governance frameworks that exist, the Bank of Namibia, through its integration initiative with the SADC Central Banks, has adopted COBIT 4.1 as an IT governance framework. COBIT 4.1 has several processes that directly aid the alignment of IT to business. A study of the implementation approach of the framework at the Bank and its effectiveness in ensuring the alignment of IT to the business functions was conducted. This study used a quantitative research methodological approach. A questionnaire was developed and was completed using a stratified sample of 35 individuals chosen from a target population comprised of the IT department, executive management and IT compliance champions in the Bank. The findings from the study revealed that a good understanding of what corporate and IT governance entails was evident in the Bank. Ninety-seven percent of the respondents indicated that IT is a key strategic tool that can be leveraged to achieve business goals. In the age of changing technology, the study revealed that the IT department is innovative and stays abreast with new technologies and trends. User awareness was not adequate and the study further revealed that only $49 \%$ of the respondents were involved in the IT governance project. The study revealed that top management supported the project. The study also reflected the positive role of IT auditing in the project. It was also noted that IT service delivery has improved and that benchmarking initiatives, as a result of the project, can lead to significant improvements in IT operations. The study revealed that the IT department understands business needs through a process facilitated by their annual departmental visits. The results from the departmental visits are well prioritised projects and IT projects that are tailored to support business goals. An IT steering committee, which was formulated, ensures that executive management is involved in key IT decisions and the reports on IT governance to the board and ensures that awareness is raised on that platform. It is recommended that an IT user awareness programme be established and an investment framework should also be established. It is recommended that the Bank adopts the COBIT 5 framework, which is a more holistic approach that focuses on governance as well as allowing for greater alignment between IT and business functions.
\end{abstract}

Keywords: information, technology, governance, implementation, accountability

\section{Introduction}

The Bank of Namibia (BoN), Namibia's central bank, was established by the Bank of Namibia Act, 1990, with the mission to be a centre of excellence - a professional and credible institution - working in the public interest, and supporting the achievement of the national economic development goals (Bank of Namibia, 2012).

The implementation of an Information Technology Governance (ITG) framework is an integral part of any institution's enterprise governance framework and is a requirement set by the King III report pertaining to corporate governance. The King III is a report that was developed by Dr. Mervin King, which compels the board of any institution to focus on IT governance as a key governance pillar.IT governance has, thus, become an important aspect, which is why this study aims to examine the implementation of that process at the Bank of Namibia and how effective it has been in reaching the objectives herein. 


\subsection{Background to the Problem}

ITG (Information Technology Governance) projects implemented within the SADC (Southern African Development Community) region, as well as in Namibia, have either not completely started or have taken longer to implement than what was required. This implies that ITG appears to be a challengeand is either not well understood or the proper implementation approaches have not yet been identified. ITG is meant to bridge the gap between IT initiatives and business goals to ensure that IT only takes on projects that support business goals; it is thus the foundation of this study to review the ITG implementation at the Bank of Namibia, how it was done, what the shortcomings and strengths are, the lessons that can be learned from the institution as well as determine if the implementation has really brought IT closer to business or whether the IT department at the bank still operates in isolation.

Pressure to comply in order to meet regulatory and national integration objectives as well as to improve internal IT operations has led to the implementation of an IT governance framework at the Bank of Namibia (BoN). It should be noted that IT governance implementations generally take a long time to implement, and, at times, the projects fail due to a lack of prioritisation and a lack of skills to apply frameworks to internal environments. As a result, this study aims to do a thorough analysis of the implementation that took place, assesses the challenges experienced, opportunities created and some of the changes that can be made for the future. It can also be noted that most organisations spend about $30 \%$ of their budgets on IT expenditure and the IT solutions do not always support the goals of the business. Hence, this is one reason for conducting this study, as it aims to assess the effectiveness of ITG implementation at the BoN in ensuring that IT goals are aligned to business goals.

\subsection{Objectives of the study}

The study aims to achieve the following objectives:

-To define information technology governance and its importance;

- To assess the implementation of information technology governance at the Namibian bank within the context of challenges and opportunities; that can be created within the Namibian bank.

- To assess the effectiveness of the implementation in ensuring alignment of information technology to business goals; and

- To explore other areas that can be explored in order to ensure greater alignment of information technology to business functions.

\section{Literature Review}

\subsection{Governance Definition}

Corporate governance involves a set of relationships between a company's management, its board, its shareholders and other stakeholders. Corporate governance also provides the structure through which the objectives of a company are set and the means of attaining those objectives and monitoring performance are determined (EGIT, 2013).

To this effect, the King III report on corporate governance was published and adopted as the guiding document outlining the responsibility of the board in ensuring that organisations are well governed. The King Report or King Report 111 is a protocol document in respect of the code of business and the ethical considerations involved in conducting business in many parts of Southern Africa and has been adopted by many countries in Southern Africa, including the Republic of South Africa. It was written by a retired South African judge and regularly updated to keep pace with the rapidly changing business environment in Southern Africa.

It is recognised that IT has a pivotal role to play in improving corporate governance practices, because critical business processes are usually automated and directors rely on information

provided by IT systems for their decision-making (National Computing Centre, 2005). This incorporates both IT and MIS. The both play pivotal roles in improving corporate governance practices.

IT should be part and parcel of enterprise governance. The results of it not being on the agenda of the board and executives are that the value and opportunities of IT are not sufficiently leveraged and its risks are not well understood or mitigated. Proper IT governance and MIS are not a luxury, but is a basic necessity of modern enterprises (Guldentops, 2007).

IT governance can be defined as the responsibility of executives and the board of directors and consists of the leadership and organisational structures and processes that ensure that an enterprise's IT sustains and extends the organisation's strategy and objectives (Van Grembergen and De Haes, 2008). 


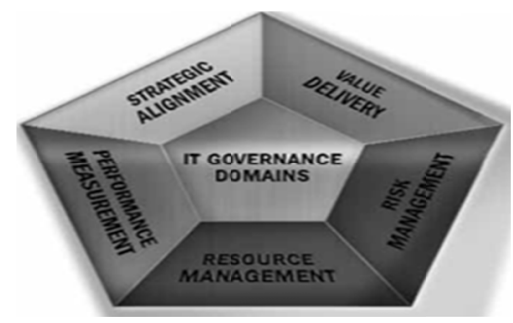

Figure 1. IT governance domains

Source: IT Governance Institute (2005:7), Pretoria, South Africa

IT governance, as depicted in Figure 1 above, has five main domains. Alignment is geared towards providing the strategic direction of IT and the alignment of IT and the business with respect to services and projects. Value delivery aims to confirm that the IT/business organisation is designed to drive the maximum business value from IT. Risk management has to do with ascertaining the processes that are in place to ensure that risks have been adequately managed. Resource management sets a high-level direction for sourcing and use of IT resources. Performance measurement verifies strategic compliance (i.e. achievement of strategic IT objectives by reviewing the measurement of IT performance and the contribution of IT to the business; National Computing Centre, 2005).

According to Figure 1 above decisions will need to be taken on the guiding principles for the entire IT function (i.e. cost effectiveness and preference to local business). IT architecture decisions will also need to be made to address how changes in IT systems will impact the current landscape. Decisions on the kind of IT infrastructure will also need to be made (i.e. virtualisation of physical environments). It will also be important to decide on which applications will be required to meet the needs of business and whether these applications will be bought or developed in-house. Project prioritisation also entails a lot in terms of decision-making, as priority needs to be given to those projects that best meet the achievement of business goals.

IT principles decisions

High-level statements about how IT is used in the business

\begin{tabular}{|c|c|c|}
\hline $\begin{array}{l}\quad \text { IT architecture } \\
\text { decisions } \\
\text { Organizing logic for data, } \\
\text { applications, and infrastruc- } \\
\text { ture captured in a set of } \\
\text { policies, relationships, and }\end{array}$ & $\begin{array}{l}\quad \text { IT infrastructure } \\
\text { decisions } \\
\text { Centrally coordinated, shared } \\
\text { IT services that provide the } \\
\text { foundation for the enterprise's } \\
\text { IT capability }\end{array}$ & $\begin{array}{l}\text { IT investment and } \\
\text { prioritization decisions } \\
\text { Decisions about how much } \\
\text { and where to invest in IT, } \\
\text { including project approvals } \\
\text { and justification techniques }\end{array}$ \\
\hline $\begin{array}{l}\text { desired business and } \\
\text { technical standardization } \\
\text { and integration }\end{array}$ & $\begin{array}{l}\text { Business applications } \\
\text { needs } \\
\text { Specifying the business need } \\
\text { for purchased or internally } \\
\text { developed IT applications }\end{array}$ & ${ }^{*}$ \\
\hline
\end{tabular}

Figure 2. IT governance decisions

Source: Weill and Ross (2004). IT Governance Decisions. Massachusetts. Harvard Business School Publications

-Identifying business requirements;

-Developing a clear understanding of candidate investment programmes;

-Analysing the alternatives;

-Defining the programme and documenting a detailed business case, including the benefits details;

- Assigning clear accountability and ownership;

-Managing the programme through its full economic life cycle; and

-Monitoring and reporting on programme performance (IT Governance Institute, 2006).

\subsection{IT Governance Structures}

When implementing IT governance, the next step would be to put the various IT governance structures in place. According to the IT Governance Institute (2005), the following structures are important for IT governance. The Chief Operating Officer must have a significant role to play in the formulation and implementation of IT strategy. The Chief Information Officer, if not a full board member, should attend board meetings when IT is on the board agenda to deliver the report and participate in the resultant discussions An IT Strategy Committee should be in place to advise and assist the board on the formulation of the IT strategy. An IT Steering Committee should be in place to assist the executive in the delivery of the IT strategy. An IT Investment Committee that has authority for the consideration, approval and on-going monitoring of the major IT-related business change projects. 


\begin{tabular}{|c|c|}
\hline When you are.... & Your role in creating the right environment ls to... \\
\hline Board and executtives & 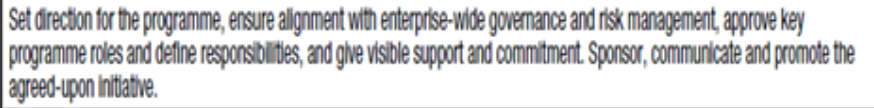 \\
\hline Business management & $\begin{array}{l}\text { Provide appropriate stakendoers and champions to dine commitment and to support the programme. Nominate key programme } \\
\text { roles and define and assign responsibilites. }\end{array}$ \\
\hline IT management & $\begin{array}{l}\text { Ensure that the business and executives understand and appredate the high-level objectives. Nominate key programme roles and } \\
\text { define and assign responsibilites. Numinate a person to drive the programme in agreement with the business. }\end{array}$ \\
\hline IT audit & $\begin{array}{l}\text { Agree on the role and reporting arrangements for audit participatoon. Ensure that an adequate level of audit participation is } \\
\text { provided thought the duration of the programme. }\end{array}$ \\
\hline Risk and compliance & Ensure an adequate level of participation through the duration of the programme. \\
\hline
\end{tabular}

Figure 3. Environment roles

Source: ISACA (2009).

In any IT governance programme, the right environment should be created. Figure 3 depicts the roles of various groups in ensuring that this environment is created. The board and top executive have to be involved in the project to set the tone from the top. Business management involvement is necessary to drive the project, whereas IT management has the role of ensuring that business managers understand the objectives of the project. IT audits will be required to see if the project is delivering as per the expectations and that appropriate controls are put in place. Risk and compliance is responsible for the monitoring process in order to ensure that controls that are put in place are complied with and that any underlying risks are managed effectively.

\subsection{Implementation Life Cycle}

The implementation life cycle of an IT governance programme is a continual improvement approach that provides guidance to enterprises addressing the complexity and challenges typically encountered during IT governance implementations (ISACA, 2009).

Introducing a governance model/framework into an organisation takes a long time. Compliance can be mandated, but cultural changes typically require several years to change personal habits. During this time, a strong executive sponsorship is required to emphasise and support the new approach (Wallace and Webber, 2014).

Phase 1 of the implementation lifecycle identifies current change drivers (an internal or external event, condition or key issue that serves as a stimulus for change) and creates, at executive management levels, a desire to change that is then expressed in an outline of a business case. Risks associated with the implementation of an IT governance programme itself are described in the business case and managed throughout the life cycle (ISACA, 2009).

Phase 2 aligns IT objectives with business strategies and risks and prioritises the most important IT goals and processes (including controls). COBIT provides a generic mapping of business goals, IT goals and IT processes to one another to help with the selection of goals. Given the defined IT goals, critical processes are defined, managed and controlled in order to ensure successful outcomes (ISACA, 2009).

Phase 3 sets a target for improvement, followed by a gap analysis to identify potential solutions. Some solutions will be quick wins and others more challenging, long-term tasks. Priority should be given to projects that are easier to achieve and likely to give the greatest benefit. Longer-term tasks should be broken down into manageable pieces (ISACA, 2009).

Phase 4 plans feasible and practical solutions by defining projects supported by justifiable business cases and developing a change plan for implementation. A well-developed business case will help ensure that the benefits of projects are identified and monitored (ISACA, 2009).

Phase 5 provides for the implementation of the proposed solutions into the day-to-day practices and the establishment of measures and monitoring systems to ensure that business alignment is achieved and performance can be measured. Success requires engagement, awareness and communication, understanding and commitment of top management and ownership of the affected business and IT process owners (ISACA, 2009).

Phase 6 focuses on the sustainable transition of the improved management practices into normal business operations and monitoring the achievement of the improvement by measuring performance metrics and the expected benefits (ISACA, 2009).

Phase 7 reviews the overall success of the initiative, identifies further governance requirements and reinforces the need for continual improvement (ISACA, 2009).

While reporting is not mentioned explicitly in any of the phases, it is a continual thread through all of the phases and iterations (ISACA, 2009). 


\subsection{Measurement}

An important part in the implementation process is the performance measurement of IT and IT as it relates to the business (Van Grembergen and De Haes, 2008).

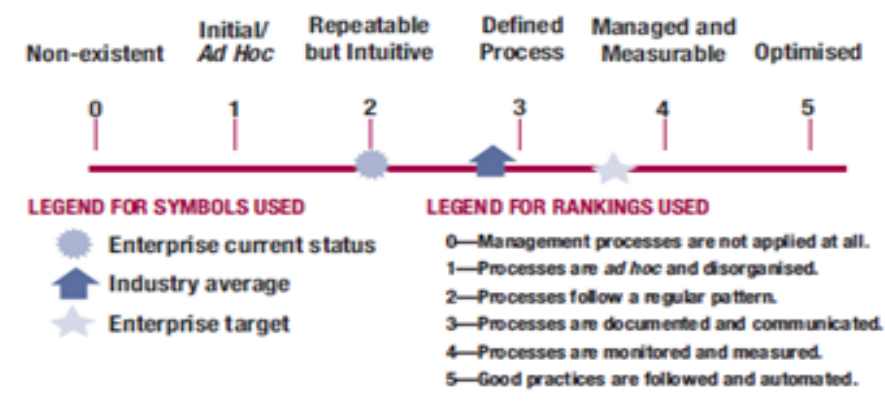

Figure 4. Maturity levels

Source: IT Governance Institute (2007). IT Alignment. Knowledge Center Research Documents, 1 November, 2013

The COBIT framework measures the maturity of IT governance processes using the maturity model above in Figure 8. Level 0 refers to no controls being in place. Level 1 means processes are there but are ad hoc and disorganised. Level 3 means processes are documented and follow a regular pattern. The desired maturity level of any organisation is a 4 or 5 across all their applicable COBIT processes, which implies that processes are monitored and measured, and, in some cases, automation has replaced manual processes.

\subsection{The Role of It Auditing}

A key component in any governance framework is the process of ensuring that board requirements are actually happening, and, conversely, that nothing that should not be happening actually is. Well governed organisations exist in an environment in which business model risks and business plans have been assessed, a positive decision in respect of risk (accept, reject, transfer or control) has been made and for those risks where a decision has been made to accept and control and for which appropriate controls have been identified and accepted (Calder, 2005).

Fraud, theft, grand larceny, natural disaster, error and system incompatibility are amongst the range of things that can contribute to business discontinuity, regulatory failures and financial losses. The purpose of IT audits is to ensure that the controls selected by the organization to deal with these issues are adequate in both their selection and application (Calder, 2005). Controls should be regularly tested to ensure that they work as intended (Calder, 2005).

The objective of IT auditing is to provide the outside directors with real, technical assurance that the IT implementation principles and the governance framework are being applied and to identify any areas of non-conformance that need to be drawn to the attention of the directors (Calder, 2007).

\section{Research Methodology}

\subsection{Target Population}

All items in any field of inquiry constitute a "Universe" or "Population" (Kothari, 2004). For the purpose of this study, this was the Bank of Namibia. Any inferences from a sample refer only to the defined population from which the sample has been selected. This can be called the target population (Banerjee and Chaudhury, 2010). In this study, the target was the individuals within the bank who were somewhat acquainted with the implementation of IT governance at the bank, which is the IT department and the Bank's management (directors and deputy directors) as well as compliance champions in each department at the Bank.

\subsection{Sample Size}

A stratified random sampling strategy was used. The target population of 35 was divided into homogenous subgroups and the random samples from each subgroup were taken (Kombo and Tromp, 2006).

The Bank of Namibia employees were divided into subsets (IT General Staff, as per their two divisions, IT Management, Bank Senior Management and Compliance champions).Based on this, an appropriate number of elements were then selected from the subsets. The sample size was chosen to be at least two-thirds of the total population. It must also be noted that the IT implementation started in 2009 and a portion of the total population had only been in employment for less than a year.

2006).

\subsection{Limitations and Delimitations of the Study}

The study is limited to the Bank of Namibia. With the maturity levels of IT governance in the country as a whole being very low, value would have been added to the study if other organisations and their learning curves could also have 
been included in the study.

Sampling was limited to the selected few due to their involvement in the implementation. If a bigger population could have been targeted, it would have raised a good indication of the awareness of the IT governance project and its goals to more staff members. Some of the management team were out of office on official business and could not participate in the study. The managers' contributions would have been valuable to the outcome of the study.

The design of the questionnaire (using the Likert scale) does not allow for other open-ended questions or comments, which would have provided good information to address the research questions in detail.

\section{Results, Discussion and Interpretation of Findings}

The figure 5 below indicates and depicts the issues that permeate corporate governance in terms of the responses elicited from the participants and is more cogently explained after the figure 5 hereunder:

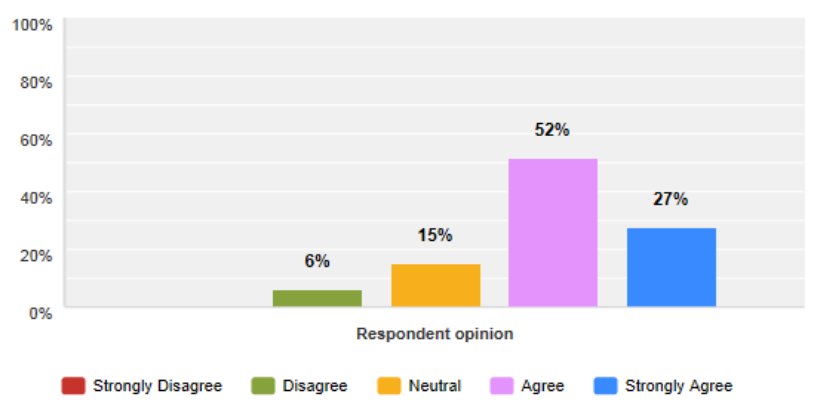

Figure 5. Corporate governance

Responses in Figure 5 reveal that $6 \%$ of the participants' disagreed ( $0 \%$ strongly disagreed and $6 \%$ disagreed), $15 \%$ were unsure and $79 \%$ agreed (52\% agreed and $27 \%$ strongly agreed) that corporate governance is the structure through which the objectives of a company are set and the means for attaining those objectives and monitoring performance are determined. It was imperative to start with determining what corporate governance is, as this is the overarching concept from which IT governance is derived. Enterprise governance considers the whole picture to ensure that strategic goals are aligned and good management is achieved (Internal Federation of Accountants, 2004).

It is also important to know and maintain good governance, as many corporate failures have been attributed to the lack of good corporate governance. Corporate governance failures that have led to company failures are the culture and tone at the top, especially if these factors do not promote high ethics, there are dominant chief executive officers, there is a lack of sufficient board oversight over their chief executive and internal control weaknesses (Internal Federation of Accountants, 2004).

\subsection{What Information Technology Governance is?}

The question aimed at understanding if the respondents' understood the meaning of information technology governance.

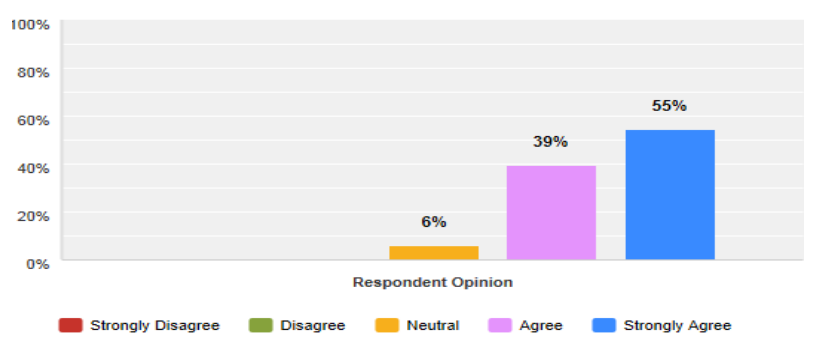

Figure 6. IT governance

The responses in Figure 6 reveal that $0 \%$ of the participants disagreed $(0 \%$ strongly disagreed and $0 \%$ disagreed) with the correct definition of ITgovernance, $6 \%$ were unsure and $94 \%$ agreed (39\% agreed and 55\% strongly agreed) that IT governance is an important part of corporate governance and aims to extend organisational objectives. Understanding IT governance and the value it can give an organisation helps to show that, although IT is not a key competency of most organisations, the survival of the organisation depends on how well its IT operations support business goals and objectives, which is the reason why organisations turn to IT governance to close the difference between what they expect from their IT function and the value it is delivering (Wallace and Weber,2014).

\subsection{Leveraging Information Technology}

The question aimed at understanding if respondents' agreed that IT can be leveraged to enable business goals to realise. 


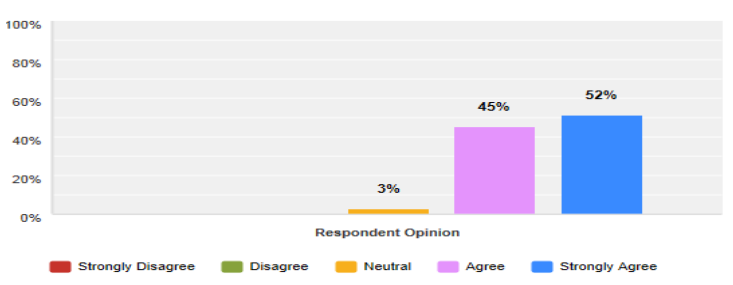

Figure 7. Leveraging IT

Responses in Figure 7 reveal that $0 \%$ of the participants' disagreed ( $0 \%$ strongly disagreed and $0 \%$ disagreed), $3 \%$ were unsure and $97 \%$ agreed ( $45 \%$ agreed and 52\% strongly agreed) that IT can be a strategic partner to a business. An organisation needs governance and planning processes that ensure that business leaders are aware of new technologies and trends and are able to determine which IT investments are right for the organisation. Strategic alignment considers the processes and structures needed to ensure the business strategy is properly informed of technology possibilities and that IT investment are appropriately targeted (Deloitte and Institute of Chartered Accountants in Australia, 2010).

\subsection{Staying Abreast with Information Technology}

The question aimed at understanding if respondents' were of the opinion that the IT department at the bank is innovative when it comes to keeping up with technological trends.

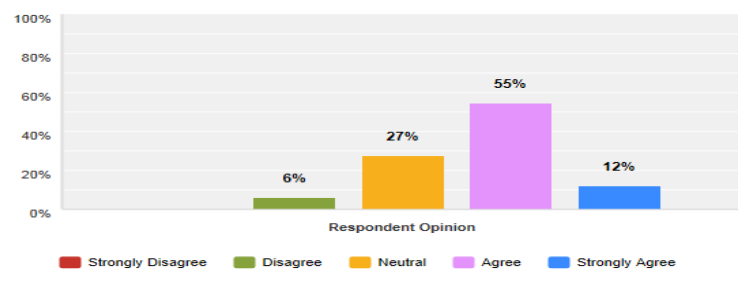

Figure 8. Staying abreast

The responses in Figure 8 reveal that $6 \%$ of the participants' disagreed ( $0 \%$ strongly disagreed and $6 \%$ disagreed), $27 \%$ were unsure and $67 \%$ agreed (55\% agreed and $12 \%$ strongly agreed) that the IT department adopts new technologies. The IT department is thought to be innovative. It should be considered whether IT is enabling the organisation to take advantage of the potential of new technologies. Furthermore, it is important to ascertain if the business is aware of the potential of new technologies and how it plans to exploit them (Deloitte and Institute of Chartered Accountants in Australia, 2010).

The use of multi-media, mobile computing, social media and collaboration platforms are poised for explosive growth with the deployment of the National Broadband Network. "Doing the right things" in the world of IT is no longer solely about the efficient processing of transactions. The new technologies have the potential to be truly disruptive and transformative to all spheres of business, the public sector and not-for-profits. Business leaders need to understand the opportunities and threats that these technologies may present (Deloitte and Institute of Chartered Accountants in Australia, 2010).

\subsection{High IT Budget}

The question aimed at understanding if a big proportion of the total Bank's budget was spent on IT investments.

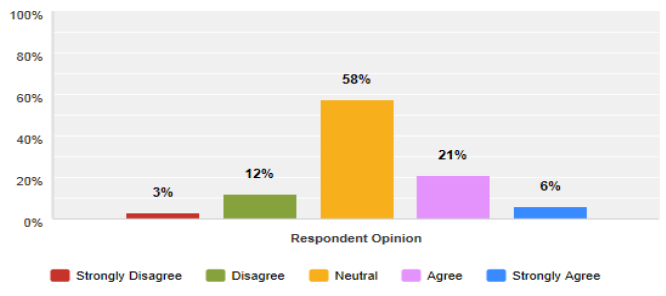

Figure 9. IT Budget

The responses to Figure 9 reveal that $15 \%$ of the participants' disagreed ( $3 \%$ strongly disagreed and $12 \%$ disagreed), $58 \%$ were unsure and $27 \%$ agreed ( $21 \%$ agreed and $6 \%$ strongly agreed) that the IT budget takes a huge chunk of the bank's budget.

A survey error, according to Jarrett (2011), can be observed in this question as construction was wrong and a better question could have read, "A lot is spent annually on IT expenditure" to gauge if respondents' think that IT investments cost a lot. The wrong constructions, however, lets the respondents' try and ascertain if budgets are less or more than 
$30 \%$, of which they were not sure of the actual figures. The responses, however, can still be used to significantly show the lack of awareness of how the bank's budget is allocated, and, furthermore, analyse the break-up of the remaining $42 \%$ to assess the intended aim.

Of the $42 \%$ who gave a certain answer, $64 \%$ agreed that IT takes up a huge amount of the Bank's budget. IT consumes a large share of the company's operating budget and has a voracious appetite for further resources (Wallace and Weber, 2014).

IT spending needs to be well managed and should be transparent. Value IT (Val IT) provides guidelines, processes and supporting practices to assist the board and executive management in understanding and carrying out their roles related to such investments. Effective application of the principles, processes and practices contained in value IT will enable organisations to increase the understanding and transparency of cost, risks and benefits, resulting in much more informed management decisions (IT Governance Institute, 2006).

\section{Implementation}

\subsection{User Awareness}

The question aimed at ascertaining whether user awareness relative to IT governance about staff is done sufficiently

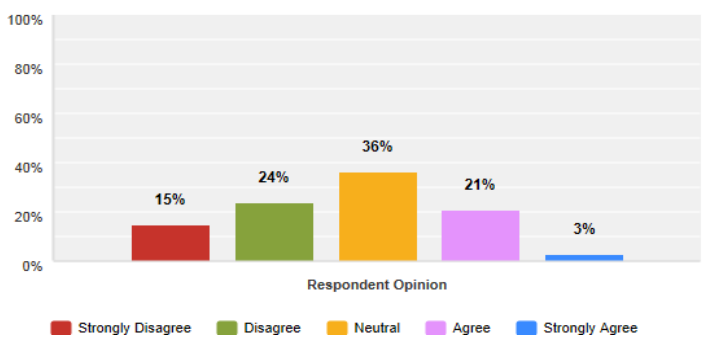

Figure 10. User awareness

Responses in Figure 10 reveal that $39 \%$ of the participants' disagreed (15\% strongly disagreed and 24\% disagreed), $36 \%$ were unsure and $24 \%$ agreed (21\% agreed and 3\% strongly agreed) that the IT department does awareness to Bank staff on IT governance agendas. It can be concluded that awareness on the IT governance implementation at the bank has not been effective. Communication and cultural behaviour, based on appropriate influencing strategies are key ingredients of any IT governance improvement initiative. Effective communications will ensure that "everyone is on the same page" and that key issues have been grasped, objectives have been positively accepted by management and staff and everyone understands their role(National Computing Centre, 2005).

\subsection{Involvement}

The question aimed at ascertaining whether the respondents' were involved in the IT governance implementation project.

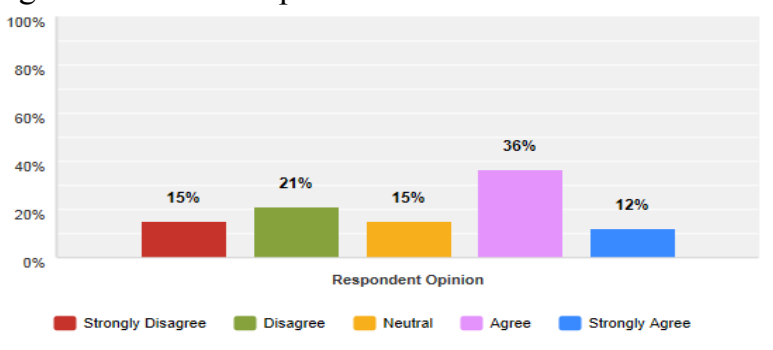

Figure 11. Involvement

Responses in Figure 11 reveal that 36\% of the participants' disagreed (15\% strongly disagreed and 21\% disagreed), $15 \%$ were unsure and $48 \%$ agreed (36\% agreed and $12 \%$ strongly agreed) that they were involved in the implementation project.

It can be concluded that a large number of individuals were involved in the implementation project, especially in the creation of documents or the review thereof. A key characteristic of any successful IT governance initiative is the establishment of an enterprise-wide approach that clearly sets out roles and responsibilities, emphasising that everyone has a part to play in enabling successful IT outcomes (National Computing Centre, 2005).

\subsection{Top Management}

The question aimed at ascertaining if the Bank'stop management is involved in the governance implementation project. 


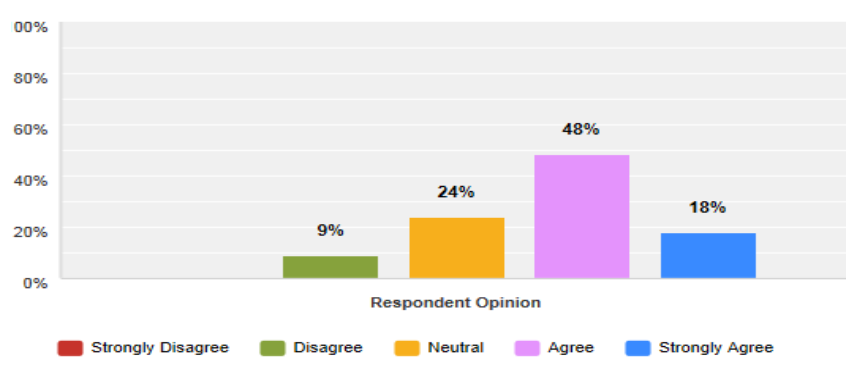

Figure 12. Top management

Responses in Figure 12 reveal that $9 \%$ of the participants' disagreed ( $0 \%$ strongly disagreed and $9 \%$ disagreed), $24 \%$ were unsure and $66 \%$ agreed (48\% agreed and 18\% strongly agreed) that the project has top management buy-in. It is important that the executives of the bank support the implementation of the project. Executive sponsorship must be obtained and the higher in the organisation that it comes from the better. If IT governance is seen as "optional," it won't work (Mercury, 2006).

\subsection{IT Auditing}

The question aimed at examining whether internal IT auditing has improved IT operations.

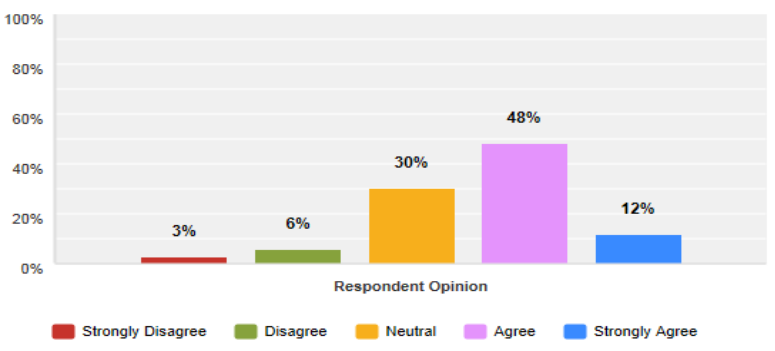

Figure 13. IT auditing

Responses in Figure 13 reveal that $9 \%$ of the participants' disagreed 3\% strongly disagreed and 6\% disagreed), $30 \%$ were unsure and $60 \%$ agreed ( $48 \%$ agreed and $12 \%$ strongly agreed) that the auditing of IT operations has led to IT improvement. IT audits look for risks that may be due to management or technical errors. IT audits verify that IT departments are aware of and abide by the laws concerning the management and retention of critical company information (Wallace and Webber, 2014). Audits are necessary for ensuring that IT departments operate on a solid foundation of policies and procedures (Wallace and Webber, 2014).

\subsection{Benchmarking}

The question aimed at examining if benchmarking against SADC Central Banks allows IT operations to be assessed, and, where possible, to be improved.

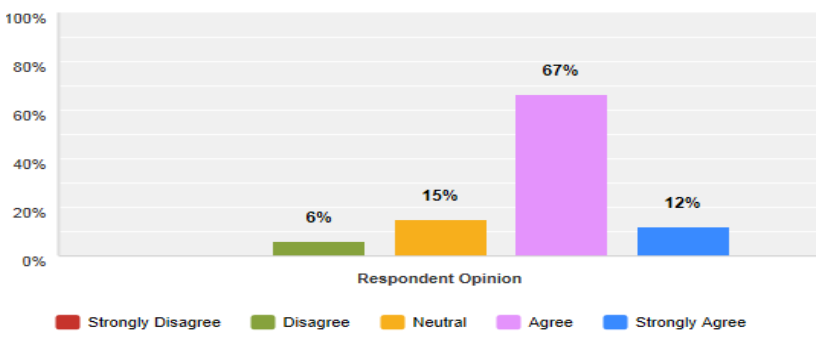

Figure 14. Benchmarking

The responses in Figure 14 reveal that $6 \%$ of the participants' disagreed ( $0 \%$ strongly disagreed and $6 \%$ disagreed), $15 \%$ were unsure and $79 \%$ agreed (67\% agreed and $12 \%$ strongly agreed) that benchmarking has led to the improvement of IT operations. Benchmarking allows the opportunity to learn from the experience of others as well as to examine current processes in order to change and improve, not only for individual organisations, but also other organisations that such organisations benchmark against. In the case of this study, proper benchmarking will lead to all SADC Central Banks implementing their governance process effectively and with less effort.

\subsection{Alignment}

In this section, apart from the graphs used, the mean, standard deviation and coefficient of correlation are calculated to assess to see whether each of the factors has contributed to the alignment of IT to the business. 


\subsection{Projects}

The question examined whether all IT systems and infrastructure support business goals.

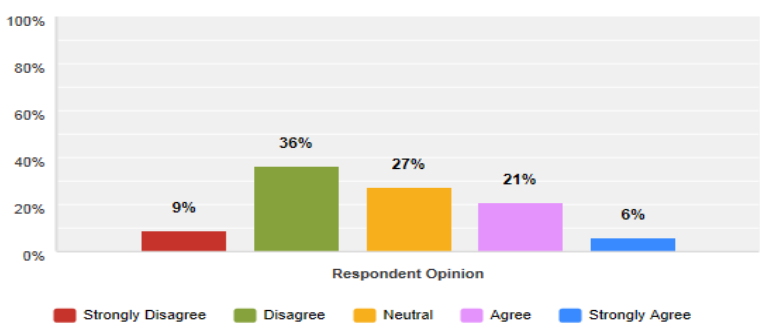

Figure 15. IT projects

Responses in Figure 15 reveal that $45 \%$ of the participants' disagreed (9\% strongly disagreed and $36 \%$ disagreed), $27 \%$ were unsure and $27 \%$ agreed ( $21 \%$ agreed and $6 \%$ strongly agreed) that IT projects support business goals. It can be concluded that not all IT systems are well aligned with business goals.

To test whether an opportunity should be pursued, the extent to which it is aligned with the organisation's strategic objectives should be assessed. All IT-related investments should contribute to at least one of the strategic objectives. Those that contribute strongly to one objective or contribute to more than one objective should be evaluated higher than those that have a lesser contribution. Investments that have lower contributions to the objective may be beneficial; however, the funding will likely be better used in investments that are more in line with the realisation of the objectives as defined in the strategy (IT Governance Institute, 2006).

Technically there is nothing with the project and is IT therefore a key factor when looking at it from the perspective of business alignment? In terms of business alignment the results indicate that they can be generalized for the entire population of the Bank of Namibia because the level of variability is low. This is reflected hereunder as follows:

Table 1. IT projects

\begin{tabular}{|c|c|c|}
\hline $\begin{array}{l}\text { Technically there is nothing wrong with the project and this is exemplified by the results obtained and } \\
\text { therefore }\end{array}$ & Frequency & Percent \\
\hline Strongly disagree & 3 & 9 \\
\hline Disagree & 12 & 37 \\
\hline Neutral & 9 & 27 \\
\hline Agree & 7 & 21 \\
\hline Strongly agree & 2 & 6 \\
\hline
\end{tabular}

According to Appendix D, the mean is 2.78, which indicates that most of the respondents' responded between Disagree (2) and Neutral (3); therefore, some IT systems are aligned to business strategy. The standard deviation of 1.083 is very low, which implies that this result can be generalised to the entire population at the Bank of Namibia, as the level of variability is low. The coefficient of correlation is 0.63 , which implies a positive relationship. Hence, it can de deduced that IT project management is a key factor when looking at IT and business alignment.

\subsection{Understanding Business}

The question aimed at examining if the IT department makes an effort to understand business as part of their annual planning process.

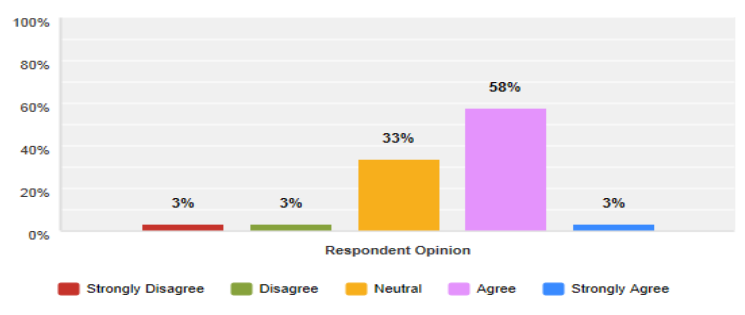

Figure 16. Understanding business

Responses in Figure 16 reveal that $6 \%$ of the participants' disagreed (3\% strongly disagreed and 3\% disagreed), 33\% were unsure and $61 \%$ agreed (58\% agreed and 3\% strongly agreed) that the IT department engages with the business and gets an understanding of their needs before planning their projects. The clear description of requirements is essential for efficient project execution (Wallace and Webber, 2014). Prototypes are essential, as they are valuable tools for demonstrating what the technical team believes the project sponsor wants (Wallace and Webber, 2014). 
Table 2. Understanding business

\begin{tabular}{lll}
\hline & Frequency & Percent \\
\hline Strongly disagree & 1 & 3 \\
Disagree & 1 & 3 \\
Neutral & 11 & 33 \\
Agree & 19 & 58 \\
Strongly agree & 1 & 3 \\
\hline
\end{tabular}

According to Appendix D, the mean is 3.545, which indicates that most of the respondents are between the Neutral (3) and Agree (4); therefore, IT does engage business in their project planning purpose. The implementation of business required systems are affected by the budgeting process, which cannot always cater for everything the business demands. The standard deviation of 0.754 is very low, which implies that this result can be generalised to the entire population at the Bank of Namibia, as the level of variability is low. The correlation coefficient is 0.7164 , which implies a strong positive relationship; hence, it can de deduced that understanding business needs is a crucial factor when looking at IT and business alignment.

\subsection{IT Strategy Alignment}

The question aimed at examining if the IT strategy is well aligned to the business strategy.

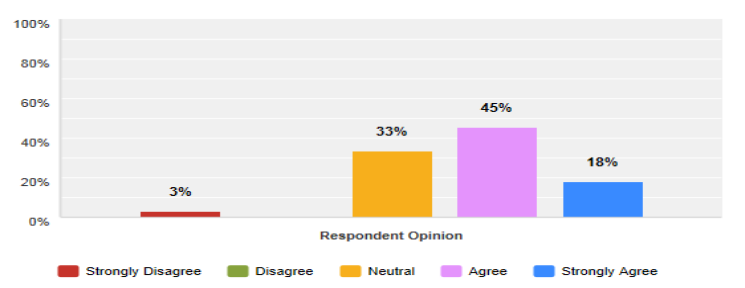

Figure 17. IT strategy alignment

Responses in Figure 4.13 reveal that 3\% of the participants' disagreed (3\% strongly disagreed and $0 \%$ disagreed), 33\% were unsure and $63 \%$ agreed (45\% agreed and 18\% strongly agreed) that the IT strategy is well aligned to the business strategy. It can be concluded that IT strategy is well aligned to the business strategy. Strategic alignment is an important driving force to achieve business value through investments in IT (Van Grembergen \& De Haes, 2008).

Table 3. IT strategy alignment

\begin{tabular}{lll}
\hline & Frequency & Percent \\
\hline Strongly disagree & 1 & 3 \\
Disagree & 0 & 0 \\
Neutral & 11 & 33 \\
Agree & 15 & 45 \\
Strongly agree & 6 & 18 \\
\hline
\end{tabular}

According to Appendix D, the mean is 3.78, which suggests that most of the respondents are between the Neutral (3) and Agree (4); therefore, IT strategy is aligned to business strategy. The standard deviation of 0.867 is very low, which implies that this result can be generalised to the entire population, as the level of variability is low. The correlation coefficient is 0.854 , which implies a strong positive relationship; hence, it can de deduced that the alignment of IT strategy to the business strategy is a crucial factor when looking at IT and business alignment.

\subsection{Project Prioritisation}

The question aimed at examining if IT projects are prioritised in such a way that what is most important to business is done first.

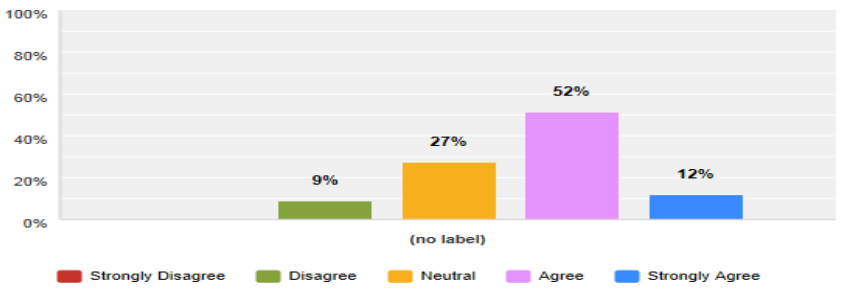

Figure 18. Project Prioritisation

Responses in Figure 18 reveal that $9 \%$ of the participants' disagreed ( $0 \%$ strongly disagreed and $9 \%$ disagreed), $27 \%$ were unsure and 64\% agreed (52\% agreed and 12\% strongly agreed) that the IT engages in project prioritisation. Over the years, the department has started taking on less projects and only those that are critical for the attainment of important business goals for the year. 
Table 4. Project prioritisation

\begin{tabular}{lll}
\hline & Frequency & Percent \\
\hline Strongly disagree & 0 & 0 \\
Disagree & 3 & 9 \\
Neutral & 9 & 27 \\
Agree & 17 & 52 \\
Strongly agree & 4 & 12 \\
\hline
\end{tabular}

According to Appendix D, the mean is 3.667, which denotes that most of the respondents are between the Neutral (3) and Agree (4); therefore, IT project prioritisation ensures that critical business needs are attended to first. The standard deviation of 0.816 is very low, which implies that this result can be generalised to the entire population at the Bank of Namibia, as the level of variability is low. The coefficient of correlation is 0.8209 , which implies a strong positive relationship; hence, it can de deduced that IT Project Prioritisation is a crucial factor when looking at IT to business alignment.

\subsection{IT Service Delivery}

The question aimed at ascertaining if IT service delivery has improved as a result of the implementation.

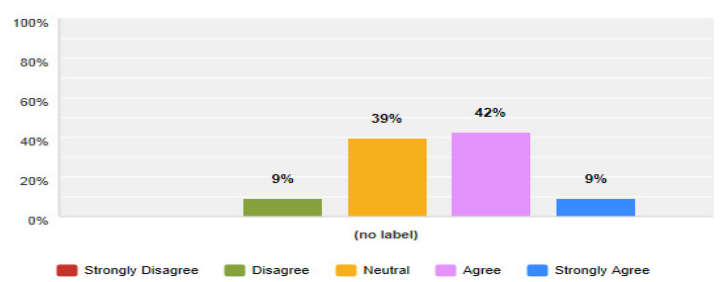

Figure19. IT service delivery

Responses in Figure 19 reveal that $9 \%$ of the participants' disagreed ( $0 \%$ strongly disagreed and $9 \%$ disagreed), $39 \%$ were unsure and $51 \%$ agreed ( $42 \%$ agreed and $9 \%$ strongly agreed) that the IT service delivery has improved. The Bank of Namibia uses the ITIL framework in conjunction with its COBIT framework. ITIL (IT Infrastructure Library) provides a best practice guidance framework for IT service management (Cartlidge, Hanna, Rudd, Macfarane, Windeback \& Rance, 2007).

All organisations depend on IT to be successful. If IT processes and IT services are implemented, managed and supported in the appropriate way, the business will be more successful, suffer less disruption and loss of productive hours, reduce costs, increase revenue, improve public relations and achieve its business objectives (Cartlidge et al., 2007).

Table 5. IT service delivery

\begin{tabular}{lll}
\hline & Frequency & Percent \\
\hline Strongly disagree & 0 & 0 \\
Disagree & 3 & 9 \\
Neutral & 13 & 39 \\
Agree & 14 & 42 \\
Strongly agree & 3 & 9 \\
\hline
\end{tabular}

According to Appendix D, the mean is 3.559, which indicates that most of the respondents are between the Neutral (3) and Agree (4); therefore, IT service delivery has improved project prioritisation and ensures that critical business needs are attended to first. The standard deviation of 0.816 is very low, which implies that this result can be generalised to the entire population at the Bank of Namibia. The coefficient of correlation is 0.8209, which implies a strong positive relationship; hence, it can de deduced that IT service delivery is a crucial factor when looking at IT to business alignment.

\subsection{IT Steering Committee}

The aim of the question was to determine if IT is discussed at executive level through the formation of an IT steering committee.

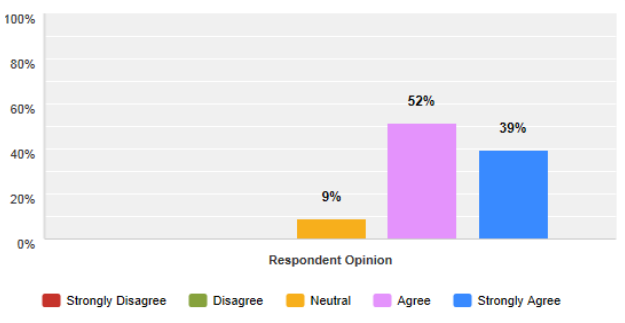

Figure 20 IT steering committee 
Responses in Figure 20 reveal that $0 \%$ of the participants' disagreed ( $0 \%$ strongly disagreed and $0 \%$ disagreed), $9 \%$ were unsure and $91 \%$ agreed (52\% agreed and 39\% strongly agreed) that the IT steering committee is important for ensuring IT is discussed at an executive level. The IT steering committee assists the executive management in the delivery (implementation) of the IT strategy. It also serves as IT governance awareness vehicles to the lower levels of the enterprise. (EGIT, 2013).

Table 6. IT steering committee

\begin{tabular}{lll}
\hline & Frequency & Percent \\
\hline Strongly disagree & 0 & 0 \\
Disagree & 0 & 0 \\
Neutral & 3 & 9 \\
Agree & 17 & 52 \\
Strongly agree & 13 & 39 \\
\hline
\end{tabular}

According to Appendix D, the mean is 4.303, which means most of the respondents are between the Agree (4) and Strongly Agree (5); therefore, an IT steering committee is important for ensuring that important IT matters are discussed thoroughly at a strategic level. The standard deviation of 0.637 is very low, which implies that this result can be generalised to the entire population at the Bank of Namibia. The coefficient of correlation is 0.886 , which implies a strong positive relationship; hence, it can de deduced that the formulation of an IT steering committee is a crucial factor when looking at IT to business alignment.

\subsection{IT project delivery}

The aim of the question was to determine if IT projects deliver appropriately in terms of time, budget and quality.

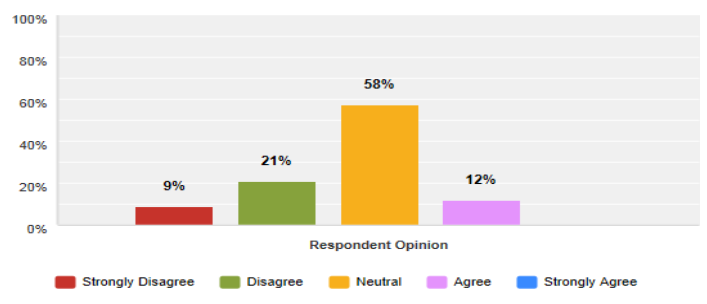

Figure 21. IT project delivery

Responses in Figure 21 reveal that $30 \%$ of the participants' disagreed (9\% strongly disagreed and 21\% disagreed), $58 \%$ were unsure and $12 \%$ agreed (12\% agreed and $0 \%$ strongly agreed) that the IT projects are delivered on time, within budget and deliver high quality. Certain factors can be attributed to projects falling short of expected goals:

-Project size being underestimated;

- The complexity of the project;

-Resource availability; and

- The physical and technical resources must also be available (Wallace and Webber, 2014).

Table 7. IT project delivery

\begin{tabular}{lll}
\hline & Frequency & Percent \\
\hline Strongly disagree & 3 & 9 \\
Disagree & 7 & 21 \\
Neutral & 19 & 58 \\
Agree & 4 & 12 \\
Strongly agree & 0 & 0 \\
\hline
\end{tabular}

According to Appendix D, the mean is 2.727, which means most of the respondents are between the Disagree (2) and Neutral (3); therefore,IT projects do not deliver on time, within the budget or with high quality. The standard deviation of 0.801 is very low, which implies that this result can be generalised to the entire population at the Bank of Namibia. The coefficient of correlation is 0.5819 , which implies a moderately positive relationship; hence, it can de deduced that IT project delivery time, budget and quality though important is not crucial when looking at IT to business alignment.

\section{Other It Governance Concepts}

\subsection{IT investment Value Delivery}

The question addressed whether investments in IT have yielded the expected returns. 


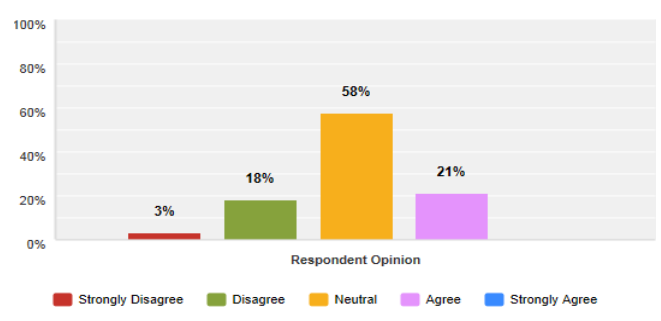

Figure 22. Return on investment

Responses in Figure 22 reveal that $21 \%$ of the participants' disagreed (3\% strongly disagreed and $18 \%$ disagreed),58\% were unsure and $21 \%$ agreed ( $21 \%$ agreed and $0 \%$ strongly agreed) that the IT investments give the appropriate Return on Investment. The study showed a neutral response, which means no confidence could be established that IT investments are creating the expected benefits. IT-enabled business investments, when managed well within an effective governance framework, provide organisations with significant opportunities to create value. Many successful organisations have created value by selecting the right investments and successfully managing them from conception through to implementation to realising the expected value. Without effective governance and good management, IT enabled business investments provide an equally significant opportunity to destroy value (IT Governance Institute, 2006).

\subsection{IT performance Measurement}

The question addressed whether IT performance is measured.

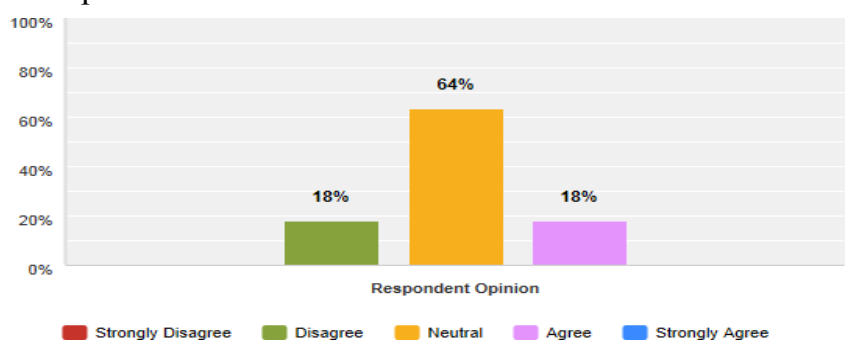

Figure 23. IT performance measurement

Responses in Figure 23 reveal that $18 \%$ of the participants' disagreed $0 \%$ strongly disagreed and $18 \%$ disagreed), $64 \%$ were unsure and $18 \%$ agreed (18\% agreed and $0 \%$ strongly agreed) that the IT performance is measured and the metrics are communicated to appropriate stakeholders. The study revealed that improvements are needed in how the IT performance is measured. The balanced scorecard is a measurement and management tool to support the achievement of strategic alignment (Van Grembergen \& De Haes, 2008).

\subsection{Enterprise IT Architecture}

The question addressed whether the impact of new or changes to existing IT systems and architecture is communicated to business.

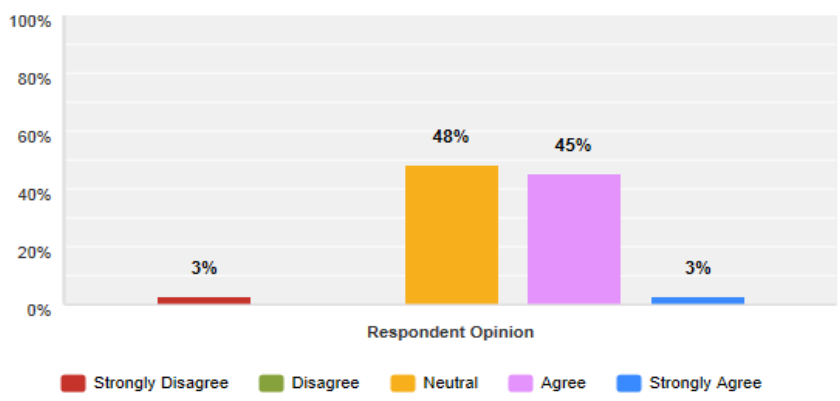

Figure 24. Enterprise IT architecture

Responses in Figure 24 reveal that 3\% of the participants' disagreed 3\% strongly disagreed and $0 \%$ disagreed), $48 \%$ were unsure and $48 \%$ agreed (45\% agreed and 3\% strongly agreed) that the impact of changes on IT architectural are communicated. The enterprise architecture refers to the way relationships among components of an organisation, including processes, people and technology, work together to create services and/or products. The architecture is organised to be efficient and effective for a business unit or a complete business. Target architecture is a blueprint that reflects the ideal or desired world. Alignment with the enterprise architecture should evaluate the extent to which investments in IT-enabled change are moving in the direction of the target architecture (IT Governance Institute, 2006). 


\subsection{ITG Reporting}

The question aimed at outlining the importance of IT governance reporting at the board level in ensuring board awareness on IT governance concepts.

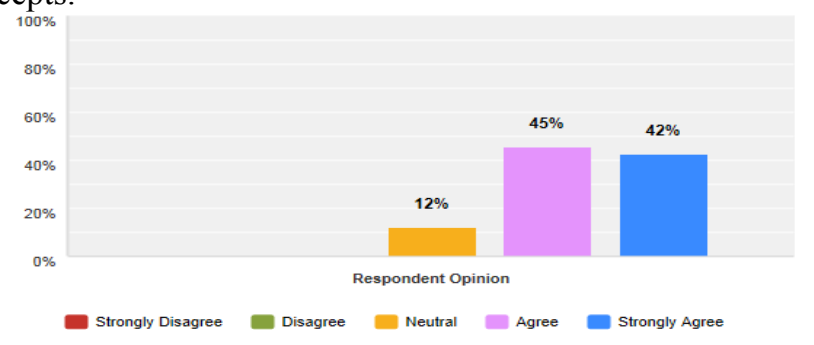

Figure 25. ITG reporting

Responses in Figure 25 reveal that $0 \%$ of the participants' disagreed $0 \%$ strongly disagreed and $0 \%$ disagreed), $12 \%$ were unsure and $87 \%$ agreed (45\% agreed and $42 \%$ strongly agreed) that reporting to the board is important in raising awareness to the board. The Board should understand the strategic importance of IT and assume the responsibility for the governance of IT and place it on the Board agenda. In order to do so, the Board should ensure that processes are in place to ensure complete, timely, accurate and accessible IT reporting from management to the Board and by the Board in the integrated report (Van der Berg and Du Rand, 2013).

\subsection{Enterprise Governance of IT}

The question aimed at assessing if IT governance should entail more than just putting controls in place and passing audit checks.

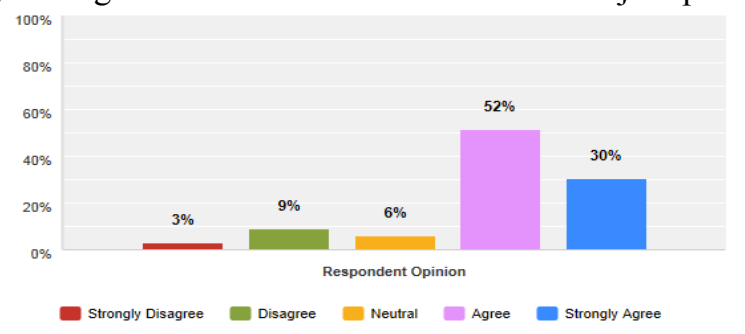

Figure 26. Enterprise governance of IT

Responses in Figure 26 reveal that 12\% of the participants' disagreed 3\% strongly disagreed and 9\% disagreed), $6 \%$ were unsure and $82 \%$ agreed (52\% agreed and $30 \%$ strongly agreed) that governance should go beyond just putting controls in place. This entails the need to separate governance from the management of IT (EGIT, 2013).

\section{Conclusions and Recommendations}

\subsection{Findings from the Study}

\subsubsection{Summary}

-IT governance is a part of corporate governance. In today's corporate governance environment where the value and importance of intellectual assets are significant, boards must be seen to extend the core governance principles to the organisation's intellectual capital, information and IT (Calder, 2007);

-IT governance is important. Those without an IT governance strategy face significant risks; those with one perform measurably better (Calder, 2007);

-Many IT governance frameworks/models exist. There are several different IT governance models that have been developed, some driven from a strategic viewpoint and others developed from tactical processes, each has its strength and weaknesses, and, therefore, business and IT must select the appropriate governance model based on the unique needs of business (Wallace and Webber, 2014);

- COBIT is a good governance framework;

-IT strategy must be well aligned to business strategy;

-An IT architecture and IT technology roadmap must be formulated to ensure that new IT systems are assessed for their impact on current architecture;

-Investment in IT must be well managed;

- IT policies must be formulated and user awareness needs to be done. If an employee awareness program does not start with policies that the average employee can understand, then there is little chance of success (Polivec Inc., 2007);

-IT performance measurement should happen and results thereof communicated to relevant stakeholders; 
-IT projects are created to solve a business problem or to implement a business strategy (Wallace and Webber, 2014); and

- The purpose of IT auditing is to ensure that controls selected by the organisation are adequate, both in their selection and application (Calder, 2005).

\subsection{Findings from the Primary Study}

- There is a good understanding of the meaning ofcorporate governance (as per $79 \%$ of the responses) and IT governance (as per $97 \%$ of the responses);

- $97 \%$ of respondents also agreed that IT can be leveraged to achieve business goals;

- $79 \%$ of the respondents agreed that the IT department is innovative and stays abreast of new technologies and trends;

- User awareness of IT governance matters, especially the IT policies and IT security, which has been inadequate;

- Only $49 \%$ of the respondents were involved in the implementation project. This is rather a low percentage in terms of buy-in from staff. Since the sample aimed to only include individuals who could have had exposure, it proves that this percentage is even significantly lower;

-Good management buy-in has been achieved, although, from the above, it can be noted that management does not share some of these matters with their subordinates;

-IT auditinghas added value and has led to the improvement of IT operations;

-Benchmarking with other SADC Central Banks assists to implement processes easily without needing to re-invent the wheel;

-The implementation of COBIT, and, specifically, the ITIL framework, has led to the improvement of IT service delivery;

-IT understands business, and, through their annual department visits to determine needs as well project prioritisation, IT projects can be tailored to support business goals;

-It was ascertained that an IT steering committee is necessary to ensure that IT is on the agenda of the executive members. The IT steering committee assists the executive management in the delivery (implementation) of the IT strategy (EGIT, 2013);

-About $88 \%$ were either unsure or disagreed that IT projects are of high quality or are delivered on time and within budget. As a result, IT project management processes need to be enhanced;

- Return on Investment should be measured and actions need to be put in place where benefits from investments are not experienced;

-IT performance should be measured and reported to respective stakeholders;

-ITG reporting to the board is key to raising awareness on this platform; and

- $82 \%$ agreed that IT governance is more than just putting controls in place and avoiding audit findings.

\section{Conclusions}

The study was undertaken to understand the IT governance project that has been implemented at the Bank of Namibia in terms of its strength and shortcomings. The study determined that a good understanding of IT governance exists at the executive level and awareness at the Board level is on-going. The study also revealed that few people were involved in the actual project and that, generally, documents such as policies and procedures have been developed as a result of the project were not communicated to the stakeholders they affect. It was also determined that IT projects at the bank are not delivered on time, within budget and are not always of good quality. The IT governance process is no exception, as it took a long time to implement and has not yielded required results as far as enforcement of developed processes is concerned. However, the study revealed that the project led to leveraging good opportunities, such as sound IT auditing practices, benchmarking and collaboration with other SADC Central Banks.

The study was also undertaken to evaluate whether IT governance is effective in ensuring IT and business alignment. The study concluded that it has been effective with a few improvements that can be noted. The study looked at key IT governance processes that result in the alignment of IT to the business functions and determined that the IT strategy is well aligned to the business strategy. It can also be concluded that IT engages business in the IT department's project planning processes and prioritises projects that support business objectives. It was also noted that IT services are well aligned to the business needs. The study also revealed that an IT steering committee provides a platform that allows IT management and business management to discuss key IT issues. Enterprise IT architecture is also effective in providing a holistic view of the landscape and assessing impact of new systems, devices, etc. on the current landscape. It can thus be concluded that IT governance does lead to better alignment.

This study will assist in pointing to the IT governance areas that the project requires more focus in order for the IT function at the bank to move from being a service provider to a strategic partner to business. 


\section{Recommendations}

\subsection{User involvement and Awareness}

Awareness of all Bank staff about IT governance and its role should be conducted. As policies that affect all staff are updated, it is important that feedback is sought and changes suggested are incorporated into policy updates. This will ensure that staffs are involved in the process. It is important that employees are required to formally acknowledge that they have read, understand and accept the requirements of the policy (Polivec Inc., 2007).

Procedures and plans that affect the IT department should be communicated to IT staff and be accessible to them. All relevant documents must then be stored at a place that is easily accessible for staff members.

It is important that as part of the user awareness programme, compliance to the policies and procedures is monitored to assess if the awareness programme was effective.

\subsection{IT project Management}

Awareness on how projects in the bank should be executed needs to be conducted. This awareness will explain the guiding frameworks, the required documents as well as where project templates can be found. It is important that templates are created to ensure that all critical points are covered and to allow standardisation.

Pre- and post-implementation reviews are required to assess firstly that all necessary aspects have been considered before taking on the project and at the end of the project to ascertain the strengths and shortcomings of a project in order to ensure a learning process for improvements in future projects.

Quality reviews should also be embedded in the project management process to assess at all levels any shortfalls on quality, on time management and budget management to allow for changes to be made while the project is on-going.

\subsection{IT Investment Management}

The challenge facing organisations is how to pick the investments that have the greatest potential value and how to execute them such that they deliver that value (Ataya, 2007).An IT investment framework needs to be established to understand current IT expenditure and well as future requirements in terms of the defined IT Technology roadmap. A framework like this should assess if current investments are yielding the required benefits and are used optimally, while also ensuring that in future planning measurable benefits of any new investment are set up front and assurance can be given to stakeholders after implementation that these benefits are being realised. The framework will, furthermore, mandate that proper feasibility studies be done to ensure that capital is not invested on systems that may not meet business needs or do not support then current architecture.

\subsection{IT Performance Measurement}

IT performance metrics should be clearly defined and performance should be measured against these defined metrics and the results reported accordingly. Any deviation from set targets must be followed by an action plan (i.e. if IT service delivery is not yielding an $80 \%$ resolution on time as per set target, a plan should be developed to improve this as underlying factors).In this example, it may be staff motivation, workload imbalance or a lack of training that influence the outcome.

\subsection{Enterprise IT Architecture}

It is not enough to just develop the architecture documents, the architecture has to be used to assess the impact of any new systems, devices, services on the current architecture in order to make informed decisions on resources required, how other components that will be affected as a result and also if the additions should be made at all.

\subsection{Enterprise Governance of Information Technology}

IT governance has to be about more than just putting controls in place, which lead to better looking IT audit reports. IT governance should, thus, not just focus on the management of IT but also on governance. COBIT 5 makes the distinction between management and governance. COBIT 5 attempts a holistic approach covering the organisation end-to-end and hence talks about the "Governance of Enterprise IT". It is, thus, recommended that the Bank of Namibia adopts the COBIT 5 framework.

Strout (2012) cites that COBIT 5 integrates value IT, Risk IT and COBIT 4.1 into a single business framework. This integrated approach facilitates more effective delivery of value to stakeholders from the more appropriate and effective governance and management of enterprise IT assets. The Bank of Namibia can build on what has already been developed using earlier versions.

Governance ensures that stakeholder needs, conditions and options are evaluated to determine balanced, agreed-on enterprise objectives to be achieved, setting direction through prioritisation and decision-makingand monitoring performance and compliance against agreed-on direction and objectives (EDM).Management plans, builds, runs and monitors activities in alignment with the direction set by the governance body to achieve the enterprise objectives (PBRM; Strout, 2012). COBIT 5 is based on a revised process reference model with a new governance domain and 
several new and modified processes that now cover enterprise activities end-to-end (i.e. business and IT function areas; Strout, 2012).

COBIT 5 allows for more IT andbusiness alignment because it provides a more holistic and complete coverage of practices reflecting the pervasive enterprise-wide nature of IT use. It also makes the involvement, responsibilities and accountabilities of business stakeholders in the use of IT more explicit and transparent (Strout, 2012).

\subsection{Areas for Future Research}

- The study should be extended to all Bank of Namibia staff in future in order to obtain a better perspective on the IT governance project initiative and its perceived benefits; and

- The study should also be extended to other organisations in Namibia to allow the maturity level of IT governance in the country to be determined as well as to develop a platform where organisations can learn from each other.

\section{Conclusion}

The primary findings assisted the researcher in answering the research questions that was formulated for this study. The study concluded that on the overall the implementation project at the Bank of Namibia has led to the improvement of IT operations and by leveraging opportunities and has led to an IT function that is better aligned to business. The secondary and primary findings suggest that the starting point to an IT governance implementation project is a good understanding of IT governance and how it fits into the corporate governance framework.

The study revealed that in implementing the project it is important to get top management buy-in yet equally important to raise awareness to all other stakeholders and involve respective people in the different phases of the project. The project, like some others, in the bank has taken a long time to implement and has not produced the expected results in all areas due to poor enforcement. Overall project management processes need to be improved. The focus on IT governance concepts, such as strategy alignment, engaging business and the formulation of an IT steering committee to name a few, are key to ensuring that IT is well aligned to business. An improvement in the utilisation of the enterprise IT architecture and the measurement of IT performance and the evaluation of IT investments for value delivery will also ensure better alignment.

\section{References}

Ataya, G. (2007). Portfolio Management-Unlocking the Value of IT Investments. http://www.isaca.org/Journal/Past-Issues/2007/Volume-4/Documents/jpdf0704-portfolio-management.pdf

Badenhorst, C. (2008). Dissertation Writing: A Research Journey. Pretoria: Van Schaik Publishers.

Banerjee, A., \& Chaudhury, S. (2010). Statistics without Tears: Populations and Samples. http://www.ncbi.nlm.nih.gov/pmc/articles/PMC3105563/

Bank of Namibia (2012). Our Vision and Mission. https://www.bon.com.na/About-Us/Our-Vision-and-Mission.aspx

Blanche, M. T., Durrheim, K., \& Painter, D. (2006). Research in Practise. 2nd Edition. University of Cape Town Press (Pty) Ltd: Cape Town.

Brynard, P. A., \& Hanekom, S. X. (2006). Introduction to Research in Management-Related Fields. 2nd Edition. Pretoria: Van Schaik Publishers.

Calder, A. (2005). IT Governance Today: A Practitioner's Handbook. Edition 1.2.United Kingdom: IT Governance Publishing.

Calder, A. (2007). IT Governance: A Pocket Guide. United Kingdom: IT Governance Publishing.

Cartlidge, A., Hanna, A., Rudd, C., Macfarane, I., Windeback, J., \& Rance, S. (2007). An Introductory Overview of $I T I L \circledR V 3.1$ st Version.ItSMF Ltd: UK.

Cliffe Dekker Attorneys. (2002). Our King Report on Corporate Governance for South Africa. What it means to you. http://www.mervynking.co.za/downloads/CD_King2.pdf

Collins, H. (2010). Creative Research. 1st Edition. Switzerland: AVA Publishing.

De Vos, A. S., Strydom, H., Fouche', C. B., \& Delport, C. S. L. (2009). Research at Grass Roots. Pretoria: Van Schaik Publishers.

Deloitte and Institute of Chartered Accountants in Australia. (2010). Business Briefing Series: 20 Issues on IT as a Strategic Partner.

http://www.charteredaccountants.com.au/ /media/Files/News\%20and\%20media/Reports\%20and\%20insights/Busi ness_briefing_series_IT_paper.ashx

EGIT. (2013). Introduction to COBIT 5. South Africa: EGIT. 
EGIT. (2013). IT Governance Fundamentals. South Africa: EGIT.

Guldentops, P. (2007). The rule of four of IT Governance. Information Systems Control Journal, 6, P1. http://www.isaca.org/Journal/Past-Issues/2007/Volume-6/Pages/The-Rule-of-Four-of-IT-Governance.aspx

Harris, S., \& Harrison, P. (2008). Recognising the Need for Val IT: Identifying Tipping Points for Value Management. Information Systems Control Journal, 3, P1.

http://www.isaca.org/Journal/Past-Issues/2008/Volume-3/Pages/Recognising-the-Need-for-Val-IT-Identifying-Tippi ng-Points-for-Value-Management1.aspx

International Federation of Accountants. (2004). Enterprise Governance: Getting the Balance Right. https://www.ifac.org/sites/default/files/publications/files/enterprise-governance-gett.pdf

ISACA (2009). Implementing and Continually Improving IT Governance. ISBN 978-1-60420-119-2, P.9. http://www.isaca.org/Knowledge-Center/Research/ResearchDeliverables/Pages/Implementing-and-Continually-Im proving-IT-Governance $1 . \operatorname{aspx}$

IT Governance Institute (2005). IT Alignment: Who is in Charge? ISBN 1-933284-14-5, P7. http://www.isaca.org/Knowledge-Center/Research/Documents/IT-Alignment-Who-Is-in-Charge.pdf

IT Governance Institute (2006). Enterprise value: Governance of IT Investments. The Business Case. ISBN 1-933284-33-1.http://www.isaca.org/Knowledge-Center/Val-IT-IT-Value-Delivery-/Documents/VAL-IT-business-c ase.pdf

IT Governance Institute. (2007). COBIT 4.1, ISBN 1-933284-72-2, P18. Available from:https://www.isaca.org/bookstore/Pages/COBIT-and-Related.aspx

Jarret, C. (2011). Surveys in practise and theory. http://www.slideshare.net/cjforms/surveys-in-practice-and-theory

Kombo, D. K., \& Tromp, D. L. A. (2006). Proposal and Thesis Writing: An Introduction. 11th reprint. Kenya: Paulines Publications Africa.

Kothari, C. R. (2004). Research Methodology: Methods and Techniques.2nd Edition. New age international publishers: New Delhi.

KPMG. (2009). Corporate Governance \& King 3. http://www.pcb.org.za/upload/files/CorporateGovernanceandKing3.pdf

Leedy, P. D., \& Ormrod, J. E. (2010). Practical Research: Planning and Design. 9thEdition. New Jersey: Pearson Education Inc.

Lund Research L. (2012). Probability Sampling [Online]. http://dissertation.laerd.com/probability-sampling.php

Maree, K. (2010). First Steps in Research. 5thEdition. Pretoria: van Schaik Publishers.

Mercury (2006). IT Governance Challenges and Best Practices. http://www.iworksmarcom.com/MercuryWhitepaper.pdf

National Computing Centre. (2005). Developing a Successful Governance Strategy. ISBN 0-85012-877-8, p.14. http://www.isaca.org/Certification/CGEIT-Certified-in-the-Governance-of-Enterprise-IT/Prepare-for-the-Exam/Stu dy-Materials/Documents/Developing-a-Successful-Governance-Strategy.pdf

Olivier, M. S. (2009). Information Technology Research: A Practical Guide forComputer Science andInformatics. 3rd Edition. Pretoria: Van Schaik Publishers.

Pellisier, R. (2007). Business Research Made Easy. 1st Edition. Cape Town:Juta \& Co.

Polivec Inc. (2007). Effective Employee Awareness5 Keys to Developing an Awareness Program. http://www.meritalk.com/uploads_legacy/whitepapers/Polivec_Effective_Employee_Awareness_White_Paper.pdf

Rajasekar, S., Philominathon, P., \& Chinnatambi, V. (2013). Research Methodology. Available from:http://arxiv.org/pdf/physics/0601009.pdf.

Singh, Y. K. (2006). Fundamental of Research Methodology and Statistics. New Age International Publishers: New Delhi.

Stroud, R. E. (2012). Comparing COBIT 4.1 and COBIT 5. http://www.isaca.org/COBIT/Documents/Comparing-COBIT.pdf

Sylvester, D. (2008). SADC ITG Training. SADC IT Forum 2009. Mon 18th August.

Sylvester, D. (2012). BON IT Architecture process. Bank of Namibia Head Office. Tue 22th May. 
Twycross, A., \& Shields, L. (2004). Validity and reliability - What's it all about? https://www.rcn.org.uk/_data/assets/pdf_file/0012/9210/Validity_1.pdf

Van den, B. M., \& Du, R. L. (2013). IT Governance-Demystifying the IT Board Reporting. http://www.itsmf.org.za/index.php/2013-03-12-07-35-18/smexa-13/marius-van-der-berg-_-leon-du-randt_it-govern ance-and-board-reporting-july-2013-pdf?format=raw

Van Grembergen, W., \& De Haes, S. (2008). Implementing Information Technology Governance: Models, Practices, and Cases. 1stEdition. New York: IGI Publishing. http://dx.doi.org/10.4018/978-1-59904-924-3

Wallace, M., \& Webber, L. (2014). IT Governance: Policies and Procedures. 2014 Edition. New York: Wolters Kluwer Law \& Business.

Weill, P., \& Ross, W. (2004). IT Governance: How Top Performers Manage IT Decision Rights for Superior Results. 1stEdition. Massachusetts: Harvard Business School Publishing.

Welman, C., Kruger, F., \& Mitchell, B. (2005). Research Methodology. 3rdEdition. Cape Town: Oxford University Press Southern Africa.

Yildirim, T. (2013). Convenient Quality Control for IT Governance Aware Enterprises. http://www.isaca.org/Journal/Past-Issues/2013/Volume-1/Pages/Convenient-Quality-Control-for-IT-Governance-a ware-Enterprises.aspx

\section{(cc) EY}

This work is licensed under a Creative Commons Attribution 3.0 License. 